\title{
Práticas reprodutivas lésbicas: reflexões sobre genética e saúde
}

\author{
Lesbian reproductive practices: reflections on genetics and health
}

Camila Vitule ${ }^{1}$

Rosana Machin ${ }^{1}$

Márcia Thereza Couto ${ }^{1}$

${ }^{1}$ Departamento de

Medicina Preventiva,

Faculdade de Medicina,

Universidade de São

Paulo. Av. Doutor Arnaldo

455/2221, Cerqueira César. 01246-903 São Paulo SP

Brasil.

camilavitule@hotmail.com
Abstract The relationship between science, technology and capital, which are intrinsic to Reproductive Technologies (RT), makes them a possibility of reproductive choice and an alternative for lesbians who wish to have children. The article seeks to reflect on the projects formulated based on the statements of lesbian couples who had used or had plans to use RT. Interviews were conducted with eight couples of women with ages between 26 and 45, all self-declared Caucasians, who had completed higher education and were living in the Greater São Paulo region between 2010 and 2011. The results reveal the preference of the respondents for donor sperm originating from a sperm bank and also the importance placed on information on the family history of health of the donor. A noteworthy finding is the interest in importing from an American sperm bank, because of an alleged limited availability of samples in Brazil and the fact that they provide more information about the donors. Thus, while RT enable non-biological parenting, genetics is considered important thereby contributing to the medicalization of parenthood.

Key words Reproductive technologies, Medicalization, Genetics
Resumo A relação entre ciência, tecnologia e capital, intrínseca às Tecnologias Reprodutivas (TR), torna estas uma possibilidade de escolha reprodutiva e uma alternativa para lésbicas que querem ter filhos. $O$ artigo se propõe a refletir sobre os projetos formulados a partir dos depoimentos de casais de lésbicas que utilizaram ou que tinham planos de utilizar as TR. Foram entrevistados oito casais de mulheres com idade entre $26 e$ 45 anos, todas autodeclaradas brancas e com nivel superior completo, residentes na Grande São Paulo/SP, entre 2010-2011. Os resultados revelam a preferência das entrevistadas pelo doador proveniente de banco de esperma e também a valorização da informação sobre o histórico familiar de saúde do doador. Destaca-se o interesse pela importação de sêmen de banco americano, em razão de uma alegada pouca disponibilidade de amostras no Brasil e por ele conter mais informações sobre os doadores. Assim, ao mesmo tempo que as TR possibilitam uma parentalidade não biológica, a genética é valorizada concorrendo para uma medicalização do parentesco.

Palavras-chave Técnicas reprodutivas, Medicalização, Genética 


\section{Introdução}

A expansão da produção de serviços, o desenvolvimento tecnológico e o aumento do consumo médico pela população, fazem parte da organização atual da prática médica, que se dá dentro dos moldes de produção capitalista.

De acordo com Donnangelo e Pereira ${ }^{1}$, em trabalho pioneiro sobre a medicalização da sociedade, a medicina pode ser encarada como método técnico (manipulação de objetos técnicos e científicos que agem sobre o corpo), que responde às práticas sociais, econômicas, políticas e ideológicas da qual também é parte. Tais práticas regulam o próprio exercer da medicina, assim como os meios de trabalho e o destino de seus produtos, dimensionando o objeto ao qual ela se aplica e lhe atribuindo significados. Logo, a medicina deve ser compreendida como histórica e construída de maneira dialética com a sociedade. Sendo assim, o termo medicalização social (ou da sociedade) é utilizado para designar modificações da prática médica em meio a inovações tecnológicas diagnósticas e terapêuticas, desenvolvimento da indústria farmacêutica e de equipamentos médicos que tem como efeito o aumento exagerado do consumo de serviços médicos e equipamentos ${ }^{2}$.

As tecnologias reprodutivas (TR) são representantes dessa organização e foram desenvolvidas inicialmente com o intuito de serem uma solução para casais heterossexuais inférteis incidindo na fecundação. Elas permitem a gravidez em contextos em que ela não é possível por meio de relações sexuais. Fazem parte das TR a maturação artificial de oócitos, as inseminações artificiais, a fertilização in vitro e a transferência, congelamento e armazenamento de embriões ${ }^{3-6}$. Sendo parte de um processo mais ampliado de medicalização da sociedade, a medicalização da reprodução possibilita uma biologia "sob controle", sendo tal controle exercido social e culturalmente pelo escrutínio médico. No entanto, suas práticas revelam ambiguidades na medida em que alimentam a busca por filhos biológicos, ao mesmo tempo em que permitem a separação do material genético dos indivíduos que o geraram trazendo diversas questões relativas ao vínculo biológico da criança gerada ${ }^{7}$.

O Brasil ainda não conta com uma legislação específica sobre o uso dessas tecnologias e as regras orientadoras para os procedimentos são aquelas definidas pelo Conselho Federal de Medicina (CFM), através de resoluções (a primeira delas - Resolução CFM No $1.358 / 92)^{8}$, tornando a medicina construtora de significados sobre pro- criação, parentalidade e família ${ }^{9}$. A partir de 2013 a nova resolução amplia o uso das práticas para qualquer pessoa, independentemente da existência de um quadro de infertilidade. Ela define os sujeitos aos quais as técnicas podem ser aplicadas - “todas as pessoas capazes” e torna explícito que "é permitido o uso em relacionamentos homoafetivos e pessoas solteiras”. Substitui a definição das técnicas, antes consideradas como sendo voltadas para resolver problemas de infertilidade, para "auxiliar na resolução dos problemas de reprodução humana, facilitando o processo de procriação"10. A mudança na expressão "problemas de infertilidade" para "problemas de reprodução humana" faculta a utilização das técnicas em outros contextos que não os casos definidos como inférteis, com problemas de saúde para conceber. Importa referir que o trabalho de campo desse estudo ocorreu antes da mudança normativa.

A relação entre ciência, tecnologia e capital possibilita a ampliação dos serviços de reprodução assistida e influencia o imaginário das pessoas, que passam a considerar as TR como uma das possibilidades de escolha reprodutiva em face da impossibilidade desta ocorrer por meio de relação sexual $^{11}$. Através da doação de óvulos, de sêmen, de embriões e através da mãe substituta, as TR possibilitam a separação entre parente biológico e parente social ${ }^{12-14}$, instaurando a possibilidade de a ordem reprodutiva ser baseada em escolhas e direitos individuais ${ }^{15}$, mesmo havendo indicações e determinações médicas a depender do caso.

$\mathrm{Na}$ prática das clínicas reprodutivas, um casal de mulheres pode por meio do acesso às tecnologias tomar parte em processos que envolvem escolhas relativas a qual das mulheres irá gestar, quais as substâncias biogenéticas envolvidas (por meio de material genético de terceiros) e as características fenotípicas buscadas no material genético doado. Nesse contexto a ciência proporciona a realização da reprodução dispondo de instrumentos para materializar significados culturais expressos em noções sobre família, classificações fenotípicas e raciais e histórico genético dos doadores. Como realizar uma correspondência fenotípica entre sêmen doado e sua receptora? Quais os elementos envolvidos nessa decisão? Introduzir a ideia de escolha em fatos referidos à natureza implica reconhecer a introdução de valores na natureza ${ }^{16}$, apesar do reconhecimento por parte dos envolvidos de que as maiores decisões nesses processos são promovidas pela natureza. Assim, as pacientes se percebem "dando uma chance para a natureza" ao buscar uma gravidez não possível pela via tradicional (relações sexuais). 
A ideia de "uma chance à natureza" é usada para justificar o processo de medicalização da reprodução operado pelas clinicas reprodutivas ${ }^{16}$, onde por meio de um processo artificial guiado pela biotecnologia busca-se camuflar os elementos referidos aos significados sociais e culturais atribuídos aos chamados fatos da natureza, ou seja, nossas noções sobre parentesco. Ademais, a ideia de que a tecnologia melhora o desempenho daqueles elementos referidos como do âmbito da natureza é uma constante no discurso desse campo $^{17}$.

A expressão "práticas reprodutivas lésbicas" tem sido empregada pela literatura internacional para se referir à reprodução entre casais de lésbicas por meio do acesso às tecnologias reprodutivas $(\mathrm{TR})^{18,19}$. No presente artigo essas práticas são abordadas por meio da construção de um projeto de filiação que valoriza as características fenotípicas e o histórico de saúde na escolha do doador de material genético.

\section{Metodologia}

O presente artigo se propõe a discutir concepções de genética e hereditariedade na constituição familiar tomando como referência empírica pesquisa realizada com casais de lésbicas que buscaram as TR como forma de concretizar o projeto de ter filhos. Ele guarda relação com uma pesquisa mais ampla $a^{6,20,21}$. O objeto de investigação foram as novas configurações familiares e a demanda por filhos no contexto de casais homossexuais (masculinos e femininos) por meio da adoção e/ ou do uso de TR.

A etapa empírica da pesquisa ocorreu entre os anos de 2011 e 2012 e foi realizada segundo o referencial da pesquisa qualitativa. A entrevista em profundidade foi a técnica de produção de dados privilegiada ${ }^{22}$, com base em roteiro pré-estabelecido contemplando aspectos como vivência da sexualidade, a trajetória afetivo-sexual; concepções de gênero, família e reprodução; autonomia, independência e laços de família e parentesco; projeto de filiação, expectativas e vivência no uso de tecnologias reprodutivas. As entrevistas foram realizadas tanto com casais femininos quanto com masculinos. Foram entrevistados tanto casais que planejavam ter filhos, e que pensavam nos meios para sua concretização quanto casais que já haviam concretizado a adoção ou a utilização de TR. O estudo limitou-se à Grande São Paulo - cidade de São Paulo e municípios da Grande São Paulo. No total, foram rea- lizadas 14 entrevistas, com 26 sujeitos. Doze delas foram realizadas com ambos os sujeitos do casal conjuntamente. No recorte aqui proposto utilizaremos os dados empíricos advindos das entrevistas com oito casais de lésbicas que optaram pelo uso de tecnologias reprodutivas, totalizando 16 entrevistadas.

As mulheres tinham de 26 a 45 anos, sendo a média das idades de 34,4. Todas se autodeclararam brancas e tinham nível superior completo. Esse perfil não foi buscado, mas corresponde às usuárias de tecnologias com alto custo. As mulheres entrevistadas alegaram preferir a opção pelo uso de TR como forma de efetivação da vontade de ter filhos. Neste sentido, três casais tinham planos concretos de utilizar TR, quatro já haviam feito uso de TR - sendo que um deles teve sucesso no tratamento, já tendo um menino - e um casal alegou que gostaria de utilizar as TR.

Dado que o uso de TR para a concretização do desejo de filhos em casais de lésbicas se constitui como prática recente no país, os casos ainda são poucos e o trabalho de campo foi marcado pela dificuldade em localizar entrevistadas ou mesmo ter seu aceite em participar da pesquisa. A procura pelos sujeitos iniciou-se através do contato com comunidades LGBTT (lésbicas, gays, bissexuais, travestis e transexuais). As estratégias subsequentes foram o contato com clínicas de reprodução e a indicação a partir de pessoas dos círculos de convivência das pesquisadoras.

A análise dos dados baseou-se na interpretação hermenêutico-filosófica. De acordo com Ayres $^{23}$, é por meio do diálogo com o outro, a partir do encontro de narrativas compostas por passado, presente e futuro produzidas no encontro, que se chega a uma interpretação ou compreensão do objeto em questão. Assim, a partir da interação entre pesquisador e entrevistado, cada qual com seu horizonte de entendimento e percepção, se chega ao entendimento, que é composto pela fusão dos dois distintos horizontes. As etapas que nortearam o processo de interpretação dos dados seguiu as seguintes etapas analítico-interpretativas $^{24}$ : (1) leitura compreensiva, visando impregnação, visão de conjunto e apreensão das particularidades do material; (2) identificação e recorte temático que emergem dos depoimentos; (3) identificação e problematização das ideias explícitas e implícitas nos depoimentos; (4) busca de sentidos mais amplos (socioculturais), subjacentes às falas dos sujeitos da pesquisa; (5) diálogo entre as ideias problematizadas, informações provenientes de outros estudos acerca do assunto e o referencial teórico do estudo; e (6) elaboração 
de síntese interpretativa, procurando articular objetivo do estudo, base teórica adotada e dados empíricos.

\section{Discussão}

O estabelecimento de filiação conjunta por casais de mesmo sexo por meio do acesso às TR é prática relativamente recente no país e mesmo a adoção juridicamente oficializada com registro de dupla maternidade ou paternidade. Até dezembro de 2010, a norma médica que regulamentava o funcionamento da prática no país não facultava o acesso de casais de mulheres aos procedimentos, assim como, as normas legais não reconheciam os direitos relativos a casais de mesmo sexo quanto à constituição de família com filhos.

Griffin e Mulholland ${ }^{25}$ referem o ano de 1982, como do primeiro reconhecimento público de um casal de mulheres em Amsterdam, que virou referência ao buscar a maternidade, num momento em que não era usual casais lésbicas pensarem em filhos. $\mathrm{O}$ nascimento foi viabilizado por autoinseminação. Dunne ${ }^{26}$ descreve prática semelhante no Reino Unido, considerando a experiência de casais femininos com inseminação com doador e refere não ser muito usual na época o uso do Serviço Nacional de Saúde inglês ou mesmo clínicas privadas, em razão da resistência destes em tratar casais homossexuais. Nesse contexto, em face das resistências de aceitação da prática a solução "doméstica" parece ter sido mais utilizada com arranjos realizados entre casais de mulheres e amigos que se dispunham a doar o material genético e mesmo participar do desenvolvimento do bebê. Esse panorama vai se alterando, em especial nos Estados Unidos, em torno dos anos 90, quando teria havido um 'lesbian baby boom ${ }^{27}$.

Para os casais de mulheres que querem ter filhos, a realização do sonho da parentalidade implica em uma condição: a necessidade de obtenção de sêmen para o processo. As mulheres que narraram suas experiências afirmaram a preferência pelo doador de sêmen desconhecido, proveniente de banco de sêmen, cuja mediação é realizada pelas clínicas de reprodução assistida. Nesse contexto, valer-se de sêmen de alguém conhecido seria colocar uma terceira pessoa no projeto parental e tal fato não condizia com os seus planos de parentalidade. Há valorização da autonomia do casal na construção de um projeto de família, que não comporta a presença de um parceiro. Esta posição parece se ancorar em dois aspectos. Um receio de que esta terceira parte queira participar de forma efetiva no desenvolvimento da criança e os riscos legais que o casal de mulheres pode correr deste homem entrar na justiça visando o reconhecimento legal de sua paternidade retirando o lugar da parceira que não possui vínculos biológicos com a criança, a chamada co-mãe. Assim, os casais entrevistados afirmaram a preferência pelo doador de sêmen desconhecido, provindo de banco de sêmen, cuja aquisição é mediada pelas clínicas de RA.

Como no país a comercialização de gametas é proibida ${ }^{10}$ sendo o princípio do anonimato condição, o banco brasileiro é composto apenas por doações de sêmen e os doadores não podem receber nem mesmo ajuda de custo. Bancos e também clínicas de reprodução assistida mencionam haver muita dificuldade na obtenção de doadores. Os doadores precisam comparecer pelo menos cinco vezes ao banco antes de fazer a primeira doação. Inicialmente, fazem uma consulta médica, sorologias, espermograma, screening para várias doenças, e caso aprovados, devem colher cinco amostras de sêmen e retornar em seis meses para refazer as sorologias. Os processos envolvidos na avaliação do material a ser doado estão em conformidade com as práticas recomendadas por instituições como American Fertility Society and Human Fertilization Embriology AuthorityHFEA/UK. De acordo com integrantes dos Bancos de Sêmen, o perfil do doador costuma ser um homem identificado como um doador nato, que costuma doar (sangue, por exemplo) para ajudar as pessoas.

Diferentemente nos Estados Unidos ou mesmo na Dinamarca ocorre um processo de comercialização de células genéticas, contudo a prática não está restrita à mediação médica, havendo bancos que operam diretamente com os interessados na aquisição de sêmen ou óvulos ${ }^{28}$. Nos Estados Unidos, as TR e as práticas de seleção dos bancos de sêmen têm expandido a economia, numa retórica de neoliberalismo, competição de mercado e de escolha individual ${ }^{18}$. Tem-se, a partir dos dados da pesquisa empreendida que os casais de lésbicas brasileiros vêm fazendo parte desse mercado.

De acordo com $\mathrm{Mamo}^{29}$, que fala do contexto norte-americano, para muitas lésbicas, comprar sêmen é um caminho não somente para realizar o sonho da parentalidade, mas também uma forma de realização de uma identidade imaginada, de materialização de sua esperança de futuro e do futuro de saúde do filho a ser concebido. Sendo assim, à escolha do sêmen está imbricada a lógica 
comercial imanente à medicalização da reprodução, assim como também a importância dos laços biológicos ${ }^{17,30}$. A medicina da fertilidade torna 0 sêmen um objeto ao qual são agregados valores tanto monetário quanto simbólico. Assim, o sêmen mercantilizado oferece às clientes a chance de escolher o melhor doador e de vislumbrar um novo futuro subjetivo (e idealizado) como mães $^{29}$.

Neste contexto, dois dos elementos mais valorizados na escolha do material genético são as informações sobre o fenótipo e sobre o histórico de saúde do doador de sêmen.

As entrevistadas na pesquisa relataram a procura de doadores que tivessem o fenótipo similar ao da chamada 'co-mãe', ou seja, daquela que não iria participar do processo seja por meio da gestação, seja pelo uso de seu material genético (óvulo). Assim, se objetivava estabelecer uma semelhança fenotípica entre a co-mãe e sua família de origem com o doador de sêmen, sendo esta semelhança um critério determinante para a escolha do sêmen pelo casal. Como observa uma entrevistada Quando a gente ia fazer inseminação, a gente pensou alguém mais parecido comigo, já que ia ser com óvulo dela[...] Queria parecido comigo.

Quanto à importância dada ao fenótipo do doador na escolha do sêmen ${ }^{31}$, ao estudar casais de lésbicas que utilizaram sêmen de doador conhecido ou anônimo, observa-se que o poder de gerar a criança é atribuído às chamadas co-mães e não ao sêmen doado, na medida em que as comães participaram da decisão de ter um filho e da escolha do doador com características fenotípicas similares a elas. Corrêa ${ }^{32}$, em estudo sobre maternidade lésbica, igualmente menciona que as mulheres entrevistadas buscavam um doador que se assemelhasse à co-mãe objetivando reconhecer no filho gestado a representação da contribuição de ambas no processo. Nesse sentido, o parentesco é tomado na perspectiva de contribuição biogenética dos integrantes do casal em igual proporção, como uma partilha de material genético no ser a ser criado, independente do fato de que uma das partes esteja representada de modo simbólico pelo material genético de uma terceira parte (doador).

Nesse contexto, "ter um filho com sua carinha" aparece como sinônimo para proporcionar uma filiação que possua laços com as duas integrantes do casal. Como observa essa entrevistada Você saber que aquela criança vai nascer com as características da pessoa que você ama e é você que esta gerando. É um direito e a gente também quer ter. Gerar um filho da pessoa que a gente ama.
Para Weston ${ }^{27}$, o desejo da mãe genética é o de que a criança se pareça fisicamente com co-mãe. Deste modo, um filho ser parecido com seus pais pode significar a criação de uma continuidade étnica e cultural. Ademais, essa busca visa igualmente reforçar o laço relativamente frágil nesse processo da parceira que não terá vínculos biológicos com a criança e que, em razão de contextos legais específicos, pode não ter reconhecido seu lugar na vida da criança gestada, numa situação de separação do casal por exemplo.

Todos os casais que já haviam realizado procedimentos de TR utilizaram o banco brasileiro de sêmen pelo menos uma vez. No entanto, alegaram pouca informação acerca dos doadores e reduzido número de amostras disponíveis com as características fenotípicas demandadas no banco nacional como motivos para uso de sêmen de banco americano. Mesmo o casal que teve sucesso no procedimento de tecnologia reprodutiva com o uso de sêmen de banco brasileiro, reclama das poucas informações que possuía acerca do doador. Importa considerar nesse contexto que o acesso ao banco de sêmen no país é mediado pelos serviços de reprodução assistida e pela equipe médica, que fornece uma lista com os doadores com as características fenotípicas acordadas com o casal. Além de características fenotípicas do doador, constam dados sobre o histórico de saúde relativo à geração anterior, além de profissão e religião.

No caso do banco de sêmen americano os casais são liberados pelas clínicas para fazerem a busca do doador diretamente pelo site, onde podem ter acesso a fotos dos doadores, inclusive de quando eram crianças, informações detalhadas sobre o histórico de saúde de até três gerações pregressas. A aquisição do sêmen, por sua vez, é mediada pela clínica de Reprodução Assistida contratada pelos casais, já que é necessário que haja uma justificativa para que o material seja importado. Para a importação de sêmen, a clínica tem que entrar com um pedido na ANVISA (Agência Nacional de Vigilância Sanitária), justificando que não há sêmen com as características compatíveis às da mãe genética no banco de sêmen brasileiro, sendo necessária sua importação. Mediante a autorização do órgão, o material genético pode ser obtido no exterior pela clínica. Indicativo do aumento dessa demanda por material genético é que um dos maiores bancos de sêmen americanos abriu no ano de 2014 um escritório na cidade de São Paulo para dar suporte aos clientes ${ }^{33}$.

É importante considerar que os procedimentos realizados no Brasil garantem o anonimato 
entre doadores e receptores, sendo esta uma das razões alegadas pelos médicos para o não fornecimento de maiores informações sobre os doadores, para que não se coloque em risco o sigilo da sua identidade. Em contraposição, as entrevistadas relatam que pelo processo de importação podem acessar o site de um banco de sêmen específico e ter a oportunidade de obter mais informações sobre o doador pretendido. Observam que no site é possível verificar perfis e busca de amostras segundo determinadas características desejadas pelos consumidores. Assim, podem visualizar perfis para escolher amostras que congregam as características escolhidas como fenótipo desejado e histórico familiar de doenças, entre outras informações. Alguns itens, como foto, um áudio e mesmo uma pequena redação do doador podem ser acessados por meio do pagamento de uma taxa extra. Ou seja, é possível “conhecer” mais sobre o doador, desde que se pague para isto. Nesse contexto, é alegado pelas entrevistadas uma preferência pelo uso do banco de sêmen americano.

Uma das entrevistadas, que fez uso do banco brasileiro em uma das tentativas e fez uso também de banco americano em uma segunda tentativa, fala sobre isso: Consegue saber todas as doenças [...] Tem histórico de doença da família inteira. Inclusive do tio, pai alcoólatra, a mãe teve câncer de mama. Tudo! Isso para mim, quando a gente viu o banco de sêmen americano falou: - Nossa! A gente chegou a pensar 'ainda bem que não deu certo'[com o material do Brasil]. Porque tinha caras que a gente estava vendo que a família inteira teve câncer. E eu falei: minha avó teve câncer de mama, eu tive dois tios que morreram de câncer, eu não quero um cara com câncer. Então, coisas que se você é casada você vai saber.

Outra entrevistada observa a importância de saber as doenças familiares por meio do cadastro do banco americano, para que o filho tenha as menores chances de desenvolver uma doença: Estamos vendo inclusive sobre as informações do doador, informações dessa parte de doenças, histórico familiar de doenças, porque a gente junta o meu histórico com o dele, para tentar livrar a criança do máximo possível.

A questão da genetização do parentesco ganha maior preponderância quando se trata da importância dada pelas entrevistadas ao histórico de doenças familiares presente no cadastro do banco americano. Por meio da disponibilidade do histórico, pode-se escolher uma "linhagem" que não tenha as mesmas doenças prevalentes no histórico de família da mãe que participa geneticamente (com uso do óvulo) do processo.
No estudo de Luce ${ }^{34}$, realizado com mulheres canadenses, o screening feito pelas clínicas era considerado importante, pois a partir dele tinham informações diversas sobre o doador. Elas se preocupavam com uma possível transmissão hereditária de uma série de fatores de riscos que poderiam ser causados por traços físicos e comportamentais dos doadores, como questões de saúde mental, uso de álcool e drogas, doenças do coração, tuberculose, entre outros. As entrevistadas julgavam que, a partir da escolha de um doador com bom histórico de saúde, elas poderiam exercer controle sobre a saúde da criança a ser gerada. Há uma crença equivocada de que a transmissão de características genéticas se dá de forma linear ou direta de uma geração para outra e, nesse sentido, agir para reescrever a carga genética que se pode receber exerce um importante valor nas escolhas a serem realizadas.

Segundo $\mathrm{Mamo}^{29}$, lésbicas que fizeram uso de banco de sêmen nos Estados Unidos, também destacaram o gerenciamento de risco como questão central para as suas escolhas. Gerenciar e minimizar riscos de potenciais doenças emergiu como percepção do avanço das tecnociências em relação à seleção do sêmen para as depoentes. Sendo assim, a minimização do risco de desenvolvimento de potenciais doenças a partir da compra do "sêmen certo" é vista como fator importante de escolha do doador. Os bancos de sêmen constroem discursos sobre risco reprodutivo, capitalizando as preocupações dos consumidores sobre agravos de saúde e risco de defeitos de nascença e a maioria dos bancos nos Estados Unidos fornecem o histórico de saúde dos doadores com pelo menos duas gerações, havendo alguns que fornecem até cinco gerações anteriores.

No processo de seleção, as mulheres associam o histórico de saúde de sua família com o histórico de saúde da família do doador. A decisão do sêmen acabava sendo uma maneira de reduzir o risco de doenças do filho em potencial, sugerindo as possibilidades de traçar um mapa de saúde da criança antes de sua concepção. "Conhecer” o doador a partir do maior número de informações disponibilizadas no cadastro do banco de sêmen é parte muito importante do processo de ter um filho por esses meios e traz confiança às mulheres, uma vez que estas estão interessadas em reduzir o risco da saúde geral e genética de seu filho.

Apesar dos resultados do projeto de sequenciamento do genoma humano ter trazido certa decepção, na medida em que não encontrou uma "verdade nos genes" que indicasse com precisão os códigos envolvidos na determinação de várias 
doenças, habilidades ou desordens, não se pode negar que promoveu certos efeitos no tocante ao reforço à compreensão do lugar da genética e da transmissão hereditária nas relações familiares ${ }^{35}$. De fato, pode-se dizer que nos aproximamos mais de um contexto probabilístico do desenvolvimento de algumas patologias relacionadas a um conjunto complexo de outros elementos envolvidos na sua manifestação ${ }^{36}$.

A proliferação da crença da genética na determinação de um crescente conjunto de características tem tido profunda influência nos discursos relativos à compreensão sobre saúde e doença, que se tornaram bastante genetizadas ${ }^{18}$. Neste sentido, é difundida a crença de que a genética faz a pessoa; que ela determina as coisas que uma pessoa gosta de fazer e suas habilidades é amplamente difundida na sociedade. A noção compartilhada é a de que o parentesco é baseado em características de comportamento e na noção biomédica de laços biológicos. Desta forma, a preocupação com a herança genética de doenças promove a medicalização do parentesco ${ }^{37}$.

Nesse sentido, pode-se considerar que se por um lado cada vez mais se afirma uma ordem reprodutiva baseada em 'escolhas' e direitos individuais, ter filhos, quando ter filhos e como ter filhos, assiste-se igualmente a uma genetização do ser humano e de suas relações familiares.

\section{Considerações Finais}

Entre os casais de lésbicas que buscam as TR há confiança na tecnociência para viabilizar o projeto de família. Outras possibilidades são descartadas por não se revelarem soluções confiáveis, pois não querem correr os riscos relacionados ao uso de uma solução doméstica com doador conhecido (self-insemination/autoinseminação) pelas implicações de transmissão de doenças e pelo risco do doador poder desejar, em algum momento, se envolver com a filiação. Há também a valorização das técnicas como uma solução segura e efetiva por proporcionar um melhor controle na escolha do sêmen, melhorando a qualidade da filiação, quanto a possíveis doenças associadas à nova geração. As histórias refletem também a importância de um mercado de consumo, baseado em escolhas pessoais, que respondem a desejos na vida reprodutiva.

Contudo, no contexto dessas escolhas mesmo que esses acontecimentos mostrem um enfraquecimento da noção biológica de família, já que por meio do uso da tecnologia outras configurações impensadas podem ser criadas, a biologia ainda é parte importante no reconhecimento do que se compreende como paternidade/maternidade, mesmo que não biológica. A ideia colocada dessa maneira parece um descompasso, mas ela diz respeito à importância da semelhança física entre pais e filhos, indicadora de um possível laço biológico entre ambos, mesmo que este efetivamente não exista. Os futuros pais/mães e as clínicas de reprodução parecem preocupados em, respectivamente, acharem e fornecerem doadores que tenham semelhanças físicas com o casal, no intuito de possibilitar um reconhecimento social de pertencimento conforme já apontado por Salem ${ }^{13}$.

As escolhas realizadas durante o processo reprodutivo revelam compreensões dos casais envolvidos quanto ao significado atribuído à genética $\mathrm{e}$ aos laços construídos. Nesse contexto, conforme observado por $\mathrm{Mamo}^{29}$, o processo de acesso aos serviços reprodutivos envolve não só a realização de um desejo por filhos, por constituir uma família, mas igualmente um futuro imaginado em que as escolhas incluem um imperativo moral relativo a ter saúde, a buscar maximizar a saúde e minimizar os riscos de doenças na filiação.

A relação entre cultura e sociedade e biotecnologia e genética pode ser compreendida a partir do par gênero-parentesco ${ }^{17}$. Observa-se a ocorrência de um movimento em que o que é atribuído à "natureza" - como a concepção de um bebê - vai paulatinamente tornando-se artificial. Nesse sentido, a luta para desnaturalizar parentesco e gênero passou a ser acompanhada por uma desnaturalização da própria biologia, não somente em relação à biologia como ciência, mas também em relação aos corpos biológicos, no sentido de tornar cada vez mais difícil determinar o que é considerado estritamente biológico. Em outros termos as "novas biologias" (as práticas da atual ciência biológica) e os "novos produtos biológicos" (novas tecnologias, como criopreservação de embriões humanos, clonagem de animais, sementes transgênicas) emergem como enorme potencial de problematização do que tradicionalmente se entendia por biologia e, portanto, por biológico.

De acordo com Thompson ${ }^{38}$, as TR prometem uma combinação perfeita entre escolha comercial e afirmação de parentesco natural, permitindo que os relacionamentos e as experiências possam ser transformados em commodities e o corpo humano e suas partes comercializados ${ }^{11}$. No Brasil, a comercialização de gametas, de forma análoga ao uso de sangue, tecidos e órgãos, é proibida, podendo haver apenas doação des- 
tes. Contudo, no contexto dos procedimentos reprodutivos o uso dos gametas é cobrado pelas clínicas em razão da sua coleta, processamento e conservação. Entre 2013 e 2014 teria havido um aumento de $500 \%$ nos processos de importação de sêmen para procedimentos de $\mathrm{TR}^{33}$, em razão de uma alegada falta de doadores no Brasil ${ }^{20}$.

No exame do papel da biologia na interpretação da noção de família dentro das sociedades liberais, temos duas tendências conflitantes dentro dos discursos legal e ético sobre o papel da biologia em definir laços familiares: ao mesmo tempo em que há uma tendência em "rebiologizar" a família, ou seja, um desejo de conhecimento das origens biológicas e aclamação do DNA, há outra tendência em "desbiologizar" a família, a partir do enfraquecimento da noção biológica de família, com o reconhecimento de outros vínculos (como o afetivo) na construção de um projeto de famí$\operatorname{lia}^{39}$. As TR como instrumentos da medicalização da reprodução possibilitam tanto uma como a outra tendência, em maior ou menor medida, sendo meios e representantes dessa contradição.

Em relação aos bancos de sêmen, há clara importância atrelada aos laços biológicos, nem que estes sejam tecnologicamente forjados via escolha de doador de sêmen. Nesse contexto, a genética emergiu como chave de significado sobre a maneira como a vida é entendida. Pela escolha/compra do sêmen, os casais estão buscando moldar a si mesmos e a seus futuros por meio de escolhas. As soluções tecnológicas, para questões extremamente íntimas, acabam entrelaçando a técnica e o pessoal, não havendo clara separação entre natural e social ${ }^{38}$. Sendo assim, medicina e sociedade caminham trilhando novos significados acerca da parentalidade e da família num movimento em que cada vez mais biologia e cultura imiscuem-se tornando difícil separá-las.

As mulheres entrevistadas fazem parte do momento histórico atual no Ocidente, guiado pelas relações de mercado e no qual há vivência de um intenso individualismo e de medicalização reprodutiva. A reprodução no domínio das clínicas de RA é elemento constituinte desse cenário, ao passo que a decisão de passar por procedimentos de RA possa significar liberdade de escolha para os clientes, tais escolhas também são reguladas pelo sistema econômico num contexto de medicalização.

\section{Colaboradores}

C Vitule trabalhou na concepção, análise dos dados e redação final. $\mathrm{R}$ Machin trabalhou na concepção, no delineamento, análise dos dados e redação final. MT Couto trabalhou na concepção e redação do artigo. 


\section{Referências}

1. Donnangelo MCF, Pereira L. Saúde e Sociedade. São Paulo: Duas Cidades; 1976.

2. Correa MV. Novas Tecnologias Reprodutivas: limites da biologia ou biologia sem limites? Rio de Janeiro: Eduerj; 2001.

3. Rotania AA. Biologia Moderna, Feminismo e Ética. In: Scavone L, organizador. Tecnologias Reprodutivas -Gênero e Ciência. São Paulo: Editora da Universidade Federal Paulista; 1996. p. 167-187.

4. Correa MV. Novas Tecnologias Reprodutivas: bemvindas reflexões feminina, ética e psicanálise. Est Fem 1998; 6(1):126-137.

5. Luna N. Novas Tecnologias Reprodutivas: natureza e cultura em redefinição. CAMPOS - Revista de Antropologia Social 2004; 5(2):127-156.

6. Machin R. Sharing Motherhood in Lesbian Reproductive Practices. Biosocieties 2014; 27:1-18.

7. Montserrat JJ, Díaz, JAR. El cuerpo humano ante las nuevas tecnologías médicas: Hacia Una redefinición del nacimiento y la muerte. Rev Esp Invest Sociol 1994; 68:173-196.

8. Brasil. Resolução CFM no $1.358 / 1992$, de 11 de novembro de 1992. Adota normas éticas para utilização das técnicas de reprodução assistida. Diário Oficial da União 2011; 19 nov.

9. Ferreira MF. As novas regras para reprodução assistida na Folha de São Paulo [Internet]. In: $9^{\circ}$ Congreso Iberoamericano de Ciencia, Tecnología y Género; 2011; Sevilha, Espanha. [acessado 2013 Maio 20]. Disponível em: http://www.oei.es/congresoctg/memoria/pdf/FerreiraMaria.pdf

10. Brasil. Resolução CFM no 2013/2013, de 16 de abril de 2013. Adota as normas éticas para a utilização das técnicas de reprodução assistida, anexas à presente resolução, como dispositivo deontológico a ser seguido pelos médicos e revoga a Resolução CFM no 1.957/10. Diário Oficial da União 2013; 9 maio.

11. Ramírez-Gálvez MC. Novas tecnologias reprodutivas conceptivas: fabricando a vida, fabricando o futuro [tese]. Campinas: Universidade Estadual de Campinas; 2003.

12. Machin R. Desejo de Filhos e Infertilidade: Um Estudo Sobre a Reprodução Assistida no Brasil [tese]. São Paulo: Universidade de São Paulo; 1999.

13. Salem T. O Princípio do Anonimato na Inseminação Artificial com Doador (IAD): Das Tensões Entre Natureza e Cultura. Physis 1995; 5(1):33-68.

14. Luna N. Provetas e clones: uma antropologia das novas tecnologias reprodutivas. Rio de Janeiro: Fiocruz; 2007.

15. Strathern M. After nature: english kinship in the late twentieth century. Cambrige: Cambridge University Press; 1992.

16. Bestard J. Kinship and the new genetics. The changing meaning of biogenetic substance. Social Anthropology 2004; 12(3):253-263

17. Franklin S. Biologization Revisited: Kinship Theory in The Context of The New Biologies. In: Franklin S, Mckinnon S, organizadores. Relative Values: Reconfiguring Kinship Studies. Durham, Londres: Duke University Press; 2001. p. 302-325.
18. Mamo L. Queering reproduction: achieving pregnancy in the age of technoscience. Durham, London: Duke University Press; 2007

19. Clarke AE, Mamo L, Fosket JR, Fishman JR, Shim JK, editors. Biomedicalization. Technoscience, health and illness in the U.S. Durham, London: Duke University Press; 2010. p. 173-196.

20. Machin R, Couto MT. Fazendo a escolha certa: tecnologias reprodutivas, práticas lésbicas e uso de bancos de sêmen. Physis 2014: 24(4):1255-1274.

21. Souza C. Casais de mesmo sexo, parentalidade e novas tecnologias reprodutivas. [dissertação]. São Paulo: Universidade de São Paulo; 2014.

22. Fontana A, Frey JH. The interwiew. From strutured questions to negotiated text. In: Denzin NK, Lincoln YS. Handbook of qualitative research. Thousand Oaks: Sage Publications; 2005. p. 645-672.

23. Ayres JRCM. Hermenêutica e humanização das práticas de saúde. Cien Saude Colet 2005; 10(3):549-560.

24. Gomes R, Schraiber LB, Couto MT, Valença OAA, Silva GSN, Figueiredo WS, Barbosa RM, Pinheiro TF. O Atendimento à Saúde de Homens: Estudo Qualitativo em Quatro Estados Brasileiros. Physis 2011; 21(1):113128.

25. Griffin K, Mulholland L. Lesbian motherhood in Europe. London: Cassell; 1997.

26. Dunne GA. Opting into motherhood: lesbians blurring the boundaries and transforming the meaning of parenthood and kinship. Gend Soc 2000; 14(1):11-35.

27. Weston K. Families we choose: lesbian, gays, kinship. New York: Columbia University Press; 1997.

28. Almeling R. Sex Cells: the medical market for eggs and sperm. Berkeley, Los Angeles: University of California Press; 2011.

29. Mamo L. Fertility INC. Consumption and subjectification in U.S. lesbian reproductive practices. In: Clarke AE, Mamo L, Fosket JR, Fishman JR, Shim JK, editors. Biomedicalization. Technoscience, health and illness in the U.S. Durham, London: Duke University Press; 2010. p. 164-194.

30. Finkler K. Experiencing the New Genetics: Family and Kinship on the Medical Frontier. Pennsylvania: University of Pennsylvania Press; 2000.

31. Hayden CP. Gender, Genetics and Generation: Reformulating Biology in Lesbian Kinship. Cult Anthropol 1995;10(1):41-63.

32. Corrêa MEC. Duas Mães? Mulheres lésbicas e Maternidade [tese]. São Paulo: Universidade de São Paulo; 2012.

33. Fantástico. Mais brasileiras procuram importar sêmen de bancos internacionais. G1 - globo.com [Internet ]. 2 Ago 2015. [acessado 2015 Nov 21] . Disponível em: http://g1.globo.com/fantastico/noticia/2015/08/mais -brasileiras-procuram-importar-semen-de-bancos-internacionais.html

34. Luce J. Beyond expectation: lesbian/bi/queer woman and assisted conception. Canada: University of Toronto Press Incorporated; 2010.

35. Ramírez-Gálvez M. Corpos fragmentados e domesticados na reprodução assistida. Cad Pagu 2009; 33:83-115. 
36. Rose $\mathrm{N}$. The humam sciences in a biological age. ICS Ocasional Paper Series 2012; 3(1):1-24.

37. Finkler K. The kin in the gene: the medicalization of family and kinship in american society. Curr Anthropol 2001; 42(2):235-263.

38. Thompson C. Making Parents: The Ontological Choreography of Reproductive Technologies. Cambridge: MIT Press; 2005.

39. Weiss MG. Strange DNA: the rise of DNA analysis for family reunifications and its ethical implications. $\mathrm{Ge}$ nomics Soc Policy 2011; 7(1):1-19.

Artigo apresentado em 15/12/2015

Aprovado em 30/04/2016

Versão final apresentada em 02/05/2016 